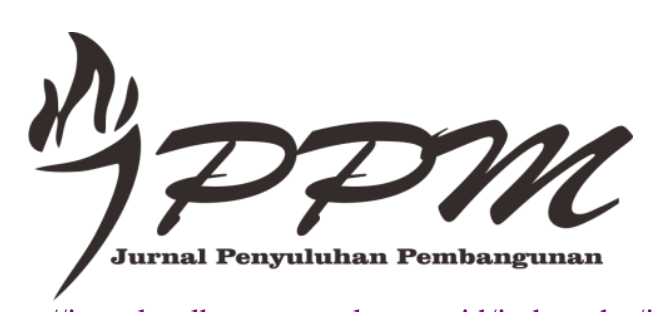

http://jurnal.polbangtanmalang.ac.id/index.php/jppm

Jurnal Penyuluhan Pembangunan Volume 1, Nomor 1 Tahun 2019

\title{
Rancangan Penyuluhan Tentang Proses Pembuatan Pupuk Organik Cair dari Urine Sapi Potong Menggunakan Mikroorganisme Lokal (MOL) Bongkol Pisang Di Desa Wonorejo Kecamatan Lawang Kabupaten Malang
}

\author{
Extension Design About the Process of Making Liquid \\ Organic Fertilizer from Urine of Beef Cattle Using Local \\ Microorganisms (MOL) Banana Bumps in Wonorejo \\ Village, Lawang District, Malang Regency
}

\author{
Triyogi Gitadevarsa*1, Setya Handayani ${ }^{2}$, Andi Warnaen ${ }^{3}$ \\ ${ }^{1,2}$ Penyuluh Swadaya Lombok Tengah Nusa Tenggara Barat \\ ${ }^{2,3}$ Program Studi Penyuluhan Peternakan dan Kesejahteraan Hewan, Polbangtan Malang \\ e-mail: *1.
}

\begin{abstract}
Abstrak
Tujuan penelitian ini adalah untuk mengetahui hasil kaji terap (pemantapan materi) tentang proses pembuatan pupuk organik cair dari urine sapi potong menggunakan MOL bonggol pisang di laboratorium limbah STPP Malang, menyusun rancangan penyuluhan tentang proses pembuatan Pupuk Organik Cair dari urine sapi potong, mendiskripsikan perilaku peternak tentang pembuatan Pupuk Organik Cair dari Urine Sapi Potong. Metode yang digunakan metode kuantitatif, di kelompoktani Karya Makmur II Desa Wonorejo Kecamatan Lawang dengan jumlah anggota 20 orang yang dimana dipilih secara Purposive Sampling. Parameter yang dilihat dari hasil kaji terap yaitu kandungan unsur hara seperti C-Organik, $\mathrm{pH}$ dan NPK. Penyusunan rancangan penyuluhan menggunakan metode analisis berdasarkan tahapan adopsi dan strategi penyuluhan. Skala pengukuran yang digunakan untuk melihat perubahan perilaku dari sasaran yaitu skala guttman, skala likert dan rating scale. Pengumpulan informasi tentang hal ini diperoleh dari kuesioner terstruktur, sedangkan analisis yang digunakan yaitu analisis deskriftif. Hasil kaji terap tentang proses pembuatan pupuk organik cair dari urine sapi menggunakan MOL bonggol pisang menunjukan secara kandungan unsur hara $\mathrm{C}$ Organik, $\mathrm{N}$, dan $\mathrm{P}$ masih belum sesuai dengan standar pupuk organik cair namun unsur hara, $\mathrm{pH}$ dan $\mathrm{K}$ sudah sesuai dengan standar pupuk organik cair. Rancangan penyuluhan yang digunakan yaitu materi tentang pembuatan MOL bonggol pisang dan pupuk organik cair dari urine sapi potong menngunakan MOL bonggol pisang, metode ceramah, diskusi dan kaji terap, dan media folder, slide dan benda sesungguhnya. Hasil penelitian menunjukan bahwa perilaku responden pada aspek pengetahuan sebesar 90\% dengan skor rata-rata 8,5 dan berada pada ranah pengetahuan dan memahami, pada aspek sikap sebesar 50\% dengan skor rata-rata 85 dan berada pada ranah menerima dan menanggapi, pada aspek keterampilan sebesar 100\% dengan skor rata-rata 16,5 dan berada pada ranah meniru.
\end{abstract}

Kata kunci : Rancangan penyuluhan, POC urine sapi, MOL bonggol pisang, Perilaku. 
Triyogi Gitadevarsa, Setya Handayani dan Andi Warnaen, Rancangan Penyuluhan Tentang Proses Pembuatan Pupuk Organik Cair dari Urine Sapi Potong Menggunakan Mikroorganisme Lokal (MOL) Bongkol Pisang Di Desa Wonorejo Kecamatan Lawang Kabupaten Malang

\begin{abstract}
The purpose of this study was to find out the results of the study of the process of making liquid organic fertilizer from beef cattle urine using banana hump MOL in the STPP Malang waste laboratory, drafting an education program on the process of making Liquid Organic Fertilizer from beef cattle urine, describing the behavior of farmers about making Liquid Organic Fertilizer from Beef Cattle Urine. The method used is the quantitative method, in the farm group Karya Makmur II, Wonorejo Village, Lawang Subdistrict, with a total of 20 people who are selected by Purposive Sampling. Parameters seen from the results of the study applied were nutrient content such as $C$ Organic, pH and NPK. Preparation of counseling designs using analytical methods based on adoption stages and extension strategies. The measurement scale is used to see changes in behavior of the target, namely the guttman scale, likert scale and rating scale. Collection of information about this is obtained from a structured questionnaire, while the analysis used is descriptive analysis. The results of the study on the process of making liquid organic fertilizer from cow urine using banana weed MOL showed that the $C$ organic nutrient content, $N$, and $P$ were still not in accordance with the standards of liquid organic fertilizer but nutrients, $\mathrm{pH}$ and $\mathrm{K}$ were in accordance with the standard organic fertilizer liquid. The counseling design used was material about making banana hump MOL and liquid organic fertilizer from beef cattle urine using MOL banana hump, lecture method, applied discussion and review, and media folders, slides and actual objects. The results showed that the behavior of respondents in the knowledge aspect amounted to $90 \%$ with an average score of 8.5 and was in the realm of knowledge and understanding, in the attitude aspect of 50\% with an average score of 85 and in the realm of receiving and responding, on aspects skills of 100\% with an average score of 16.5 and in the realm of imitation.
\end{abstract}

\title{
Keywords : Extension design, POC cow urine, Banana hump MOL, Behavior
}

\section{PENDAHULUAN}

Desa Wonorejo adalah salah satu Desa di Kecamatan Lawang yang memiliki populasi ternak sapi potong yakni 872 ekor. Pemeliharaan sapi dilaksanakan secara intensif, bahkan kelompoktani di Desa ini memiliki kandang kelompok yang permanen dan memiliki tempat penampungan urine. Tingginya populasi ternak sapi tentunya memberikan sumbangan limbah peternakan yang cukup besar baik itu feces maupun urine. Feces ternak dapat dimanfaatkan menjadi pupuk kompos dan urin sapi dapat dimanfaatkan sebagai pupuk organik cair. Daur ulang limbah ternak berperan dalam mencegah terjadinya pencemaran lingkungan, dan secara bersamaan juga meningkatkan produksi tanaman.

Pemanfaatan feces sapi menjadi kompos sudah diterapkan oleh peternak di Desa Wonorejo Kecamatan Lawang. Sedangkan untuk limbah cair belum terlalu dimanfaatkan secara optimal oleh peternak dan masih terbuang begitu saja, padahal urine sapi dapat dimanfaatkan sebagai pupuk organik cair sehingga dapat menjadi produk pertanian yang lebih bermanfaat. Pemanfaatan urine ini merupakan salah satu penerapan Zero Waste Management. 
Triyogi Gitadevarsa, Setya Handayani dan Andi Warnaen, Rancangan Penyuluhan Tentang Proses Pembuatan Pupuk Organik Cair dari Urine Sapi Potong Menggunakan Mikroorganisme Lokal (MOL) Bongkol Pisang Di Desa Wonorejo Kecamatan Lawang Kabupaten Malang

Menurut Hadisuwito (2002), pupuk organik cair merupakan dekomposisi bahanbahan organik atau proses perombakan senyawa yang kompleks menjadi senyawa yang sederhana dengan bantuan mikroorganisme.

Mikroorganisme pada pembuatan pupuk organik cair dapat di produksi sendiri dari bahan - bahan alami (lokal) untuk mengurangi biaya produksi. Mikroorganisme lokal (MOL) dapat diproduksi dari bahan nabati maupun hewani. Miroorganisme yang berasal dari nabati dapat menggunakan bonggol pisang, mengingat pisang merupakan tanaman yang mudah didapatkan di Desa Wonorejo Kecamatan Lawang. Agar peternak mau memanfaatan urine sapi, maka perlu dibuat Rancangan Penyuluhan Tentang Proses Pembuatan Pupuk Organik Cair dari Urine Sapi Potong dengan Menggunakan Mikroorganisme Lokal Bonggol Pisang di Desa Wonorejo Kecamatan Lawang Kabupaten Malang Provinsi Jawa Timur.

Tujuan dari penelitian ini adalah untik mengetahui hasil kaji terap (pemantapan materi) tentang proses pembuatan pupuk organik cair dari urine sapi potong menggunakan MOL bonggol pisang di laboratorium limbah STPP Malang, menyusun rancangan penyuluhan tentang proses pembuatan Pupuk Organik Cair dari urine sapi potong di Desa Wonorejo Kecamatan Lawang, dan mendiskripsikan perilaku peternak tentang pembuatan Pupuk Organik Cair dari Urine Sapi Potong di Desa Wonorejo Kecamatan Lawang.

\section{METODE PENELITIAN}

Penelitian dilaksanakan di Desa Wonorejo Kecamatan Lawang Kabupaten Malang. Metode yang digunakan metode kuantitatif, di kelompoktani Karya Makmur II Desa Wonorejo Kecamatan Lawang. Parameter hasil kaji terap yaitu kandungan unsur hara c-organik, $\mathrm{pH}$, dan NPK. Penyusunan rancangan penyuluhan berdasarkan hasil identifikasi wilayah dengan menggunakan metode analisis bedasarkan tahapan adopsi dan strategi penyuluhan. Untuk kajian sosial yaitu perilaku peternak tentang pembuatan pupuk organik cair dari urine sapi potong menngunakan teori bloom. Pengumpulan informasi tentang hal ini diperoleh melalui kuesioner terstruktur. Jumlah responden yaitu 20 responden yang dipilih secara Purposive Sampling dengan pertimbangan tertentu. Analisis data yang digunakan adalah deskriptif kuantitatif.

\section{HASIL DAN PEMBAHASAN}

\section{Kaji Terap}

Hasil kaji terap (pemantapan materi) pembuatan pupuk organik cair dari urine sapi potong menggunakan MOL bonggol pisang di Laboratorium Limbah STPP Malang secara kandungan unsur hara: 
Triyogi Gitadevarsa, Setya Handayani dan Andi Warnaen, Rancangan Penyuluhan Tentang Proses Pembuatan Pupuk Organik Cair dari Urine Sapi Potong Menggunakan Mikroorganisme Lokal (MOL) Bongkol Pisang Di Desa Wonorejo Kecamatan Lawang Kabupaten Malang

Tabel 1. Hasil analisis Pupuk Organik cair

\begin{tabular}{|c|c|c|c|c|c|}
\hline \multirow[b]{2}{*}{ No } & \multirow[b]{2}{*}{ Parameter } & \multirow[b]{2}{*}{ Satuan } & \multicolumn{2}{|c|}{ Kandungan } & \multirow[b]{2}{*}{ Keterangan } \\
\hline & & & $\begin{array}{c}\text { Hasil } \\
\text { Analisis }\end{array}$ & $\begin{array}{c}\text { Standar } \\
\text { Permentan }\end{array}$ & \\
\hline 1 & C-Organik & $\%$ & 0.82 & Min6 & Gravimetri \\
\hline 2 & $\mathrm{pH}$ & - & 7.37 & $4-9$ & $\mathrm{pH}$ meter \\
\hline 3 & $\mathrm{~N}$ & $\%$ & 0.06 & $3-6$ & N kjeldhal \\
\hline 4 & $\mathrm{P}_{2} \mathrm{O}_{5}$ & $\%$ & 0.004 & $3-6$ & Spectrophotometer \\
\hline 5 & $\mathrm{~K}_{2} \mathrm{O}$ & $\%$ & 4.13 & $3-6$ & Flamephotometer \\
\hline
\end{tabular}

Sumber: Dinas Pertanian Jombang

Tabel 1. Diatas dapat dilihat bahwa kandungan C-Organik masih kurang dari standar Permentan No 70/Permentan/SR.140/10/2011 yakni minimal $6 \%$. Rendahnya kandungan hara C-Organik disebabkan oleh bahan yang digunakan masih kurang tepat yaitu menggunakan gula merah sehingga asupan unsur karbon atau bahan organik (dalam bentuk karbohidrat) dan nitrogen (dalam bentuk protein, asam nitrat, amoniak, dan lainlain) yang merupakan makanan pokok bagi bakteri tidak tercukupi. Maka perlu diganti menggunakan molases. Hal ini sesuai dengan pendapat Kusuma, et. al, (2017), yang menyatakan bahwa penambahan molases dapat meningkatkan kandungan C-Organik dalam limbah isi rumen.

Tabel 1. Juga menunjukkan bahwa kandungan nitrogen $(\mathrm{N})$ masih kurang dari standar Permentan No 70/Permentan/ SR.140/10/2011 yakni 3-6\%. Rendahnya kandungan hara Nitrogen $(\mathrm{N})$ disebabkan oleh penggunaan gula merah, dikarenakan gula merah memiliki kandungan komponen nitrogen lebih rendah dibandingkan dengan molases. Hal ini sesuai pendapat Rahman dan Setyawati, (2010) yang menyatakan bahwa tetes tebu mengandung komponen nitrogen yang lebih besar dari pada sumber gula pasir dan gula jawa, disertai berbagai nutrien yang diperlukan mikroorganisme dalam composting. Menurut Huda (2013) Peningkatan N Total akibat penambahan molase tersebut dapat terjadi karena material tetes tebu juga mengandung senyawa nitrogen yang cukup tinggi. Selain penggunaan gula merah, rendahnya kandungan Nitrogen $(\mathrm{N})$ dipengaruhi oleh lamanya waktu aerasi. Semakin lama waktu aerasi yang digunakan maka semakin meningkat nilai $\mathrm{N}$ organik yang dihasilkan. Hal ini diduga karena adanya aktivitas mikroorganisme dari proses penguraian bahan organik yang mampu meningkatkan kandungan $\mathrm{N}$ organik pada biourine. Hal ini sesuai dengan pendapat Hidayati et al. (2008) bahwa kandungan $\mathrm{N}$ organik dalam biourine berasal dari bahan organik yang didegradasi oleh mikroorganisme, sehingga berlangsungnya proses degradasi sangat mempengaruhi kandungan $\mathrm{N}$ organik dalam biourine.

Tabel 1 juga menunjukkan kandungan fosfor masih kurang dari standar Permentan No 70/Permentan/ SR.140/10/2011 yakni 3-6 \%. Rendahnya kandungan hara Fosfor (P) disebabkan oleh rendahnya kandungan Nitrogen yang berada didalam pupuk organik cair. Karena kandungan Fosfor dan Nitrogen saling berkaitan. Hal ini sesuai dengan pendapat Hidayati, et. al (2011), yang menyatakan bahwa kandungan fosfor berkaitan dengan kandungan $\mathrm{N}$ dalam substrat, semakin besar nitrogen yang dikandung maka multiplikasi mikroorganisme yang merombak fosfor akan meningkat, sehingga kandungan fosfor dalam pupuk cair juga meningkat. Kandungan fosfor dalam substrat akan digunakan oleh sebagian besar mikroorganisme untuk membangun selnya. Proses mineralisasi fosfor terjadi karena adanya enzim fosfatase yang dihasilkan oleh sebagian besar mikroorganisme. Selanjutnya dikemukakan kembali bahwa dengan adanya sumber - 
Triyogi Gitadevarsa, Setya Handayani dan Andi Warnaen, Rancangan Penyuluhan Tentang Proses Pembuatan Pupuk Organik Cair dari Urine Sapi Potong Menggunakan Mikroorganisme Lokal (MOL) Bongkol Pisang Di Desa Wonorejo Kecamatan Lawang Kabupaten Malang

sumber karbon dan nitrogen yang benar-benar tersedia, maka bakteri dan jamur dapat merombak lesitin dan asam nukleat dan membebaskan fosfor. Wulandari, et. al (2015), menyatakan bahwa pada proses pengomposan jika nitrogen tersedia dalam jumlah yang cukup maka unsur hara lainnya juga tersedia dalam jumlah yang cukup maka unsur lainnya itu adalah fosfor. Pada bahan organik segar biasanya nutrient fosfor terdapat dalam bentuk organik komplek yang sulit dimanfaatkan langsung oleh tanaman untuk pertumbuhan.

\section{Rancangan penyuluhan}

\begin{tabular}{|c|c|c|c|c|c|}
\hline $\begin{array}{l}\text { Tahapan } \\
\text { Adopsi }\end{array}$ & Sadar & Minat & Menilai & Mencoba & Menerapkan \\
\hline $\begin{array}{l}\text { Perubahan } \\
\text { prilaku yang } \\
\text { diharapkan }\end{array}$ & Pengetahuan & $\begin{array}{l}\text { Pengetahuan } \\
\text { Sikap }\end{array}$ & $\begin{array}{l}\text { Pengetahuan } \\
\text { Sikap }\end{array}$ & $\begin{array}{l}\text { Pengetahuan } \\
\text { Sikap dan } \\
\text { tindakan }\end{array}$ & $\begin{array}{l}\text { Pengetahuan } \\
\text { Sikap dan } \\
\text { tindakan }\end{array}$ \\
\hline $\begin{array}{l}\text { Media yang } \\
\text { digunakan }\end{array}$ & $\begin{array}{l}\text { Terproyeksi } \\
\text { media cetak }\end{array}$ & $\begin{array}{l}\text { Terproyeksi } \\
\text { media cetak } \\
\text { lisan }\end{array}$ & $\begin{array}{l}\text { Terproyeksi } \\
\text { media cetak } \\
\text { lisan }\end{array}$ & $\begin{array}{l}\text { Media cetak } \\
\text { lisan } \\
\text { Pengetahuan }\end{array}$ & $\begin{array}{l}\text { Iisan } \\
\text { Pengetahuan }\end{array}$ \\
\hline $\begin{array}{l}\text { Hubungan } \\
\text { penyuluhan } \\
\text { dengan } \\
\text { sasaran }\end{array}$ & $\begin{array}{l}\text { Tak } \\
\text { Langsung }\end{array}$ & $\begin{array}{l}\text { Tak langsung } \\
\text { dan langsung }\end{array}$ & Langsung & Langsung & Langsung \\
\hline $\begin{array}{l}\text { Pendekatan } \\
\text { psiko-sosial }\end{array}$ & Massal & massal & Kelompok & $\begin{array}{l}\text { Kelompok } \\
\text { Perorangan }\end{array}$ & Peroragan \\
\hline Metode/teknik & $\begin{array}{l}\text { Pertemuan, } \\
\text { Radio, TV, } \\
\text { Film, brosur, } \\
\text { folder, leaflet, } \\
\text { poster }\end{array}$ & $\begin{array}{l}\text { Pertemuan, } \\
\text { radio, iv, } \\
\text { Film, brosur, } \\
\text { folder, leaflet, } \\
\text { poster. }\end{array}$ & $\begin{array}{l}\text { Diskusi } \\
\text { kelompok, } \\
\text { temu karya, } \\
\text { kursus tani, } \\
\text { demonstrasi, } \\
\text { karyawisata, } \\
\text { temu lapang }\end{array}$ & $\begin{array}{l}\text { Kunjungan, } \\
\text { belajar } \\
\text { perorangan, } \\
\text { koresponden, } \\
\text { telepon. }\end{array}$ & $\begin{array}{l}\text { Kunjungan, } \\
\text { belajar } \\
\text { perorangan, } \\
\text { koresponden, } \\
\text { telepon. }\end{array}$ \\
\hline
\end{tabular}

Berdasarkan hasil analisis rancangan penyuluhan, sasaran berada pada tahap "menilai", sehingga dapat ditentukan bahwa media yang digunakan yaitu media terproyeksi seperti video, slide, metode atau teknik yang digunakan ceramah dan diskusi kelompok. Hasil penelitian Warnaen dkk (2013) menjelaskan bahwa proses adopsi inovasi dimulai Tahap pengetahuan, selanjutnya masuk pada tahap persuasi petani mengevaluasi inovasi yang telah diterapkan oleh petani lain untuk meyakinkan apakah menguntungkan atau tidak. Pada tahap keputusan, petani melakukan pengambilan keputusan pada suatu pilihan untuk menggunakan atau menolak inovasi tersebut, apabila menguntungkan petani menerima inovasi. Tahap konfirmasi, petani yang menerapkan saling mengevaluasi inovasi yang telah diterapkan dan menceritakan kepada petani yang tidak menerapkannya. Komunitas petani dikategorikan kedalam kategori adopter yaitu tokoh masyarakat/ ketua kelompok termasuk kategori penerima dini, anggota kelompok tani termasuk kategori mayoritas dini, petani tidak berkelompok termasuk kategori mayoritas akhir, dan buruh tani termasuk kategori lagard

\section{Perilaku Peternak} Aspek pengetahuan

Tabel 3. Rekapitulasi Tingkat Pengetahuan Responden

\begin{tabular}{lccc}
\hline \multicolumn{1}{c}{ Kategori Skor } & Jumlah Orang & Rata-rata Skor & Persentase (\%) \\
\hline Rendah $(0-5)$ & - & - & - \\
Sedang(6-10) & 18 & 8,5 & 90 \\
Tinggi(11-15) & 2 & 11,5 & 10 \\
\hline Jumlah & $\mathbf{2 0}$ & & $\mathbf{1 0 0}$ \\
\hline
\end{tabular}

Sumber: Data Evaluasi, 2018. 
Triyogi Gitadevarsa, Setya Handayani dan Andi Warnaen, Rancangan Penyuluhan Tentang Proses Pembuatan Pupuk Organik Cair dari Urine Sapi Potong Menggunakan Mikroorganisme Lokal (MOL) Bongkol Pisang Di Desa Wonorejo Kecamatan Lawang Kabupaten Malang

Tabel 3 menunjukkan bahwa Pengetahuan peternak mengenai pembuatan pupuk organik cair dari urine sapi potong menggunakan MOL bonggol pisang adalah 18 responden memiliki pengetahuan sedang dan 2 responden memiliki pengetahuan tinggi.

Tabel 4. Persentase Aspek Kognitif Menurut Taksonomi Bloom

\begin{tabular}{lc}
\hline \multicolumn{1}{c}{ Dimensi Pengetahuan (C) } & Persentase (\%) \\
\hline Pengetahuan (C1) & 48,02 \\
Pemahaman (C2) & 26,55 \\
Aplikasi (C3) & 6,78 \\
Analisis (C4) & 6,21 \\
Sintesis (C5) & 12,43 \\
\hline
\end{tabular}

Sumber: Data Hasil Evaluasi, 2018.

Tabel 4 tentang persentase aspek kognitif menurut taksonomi bloom, menunjukkan bahwa responden berada pada tingkatan pengetahuan dan pemahaman. Tingkat pengetahuan ini didukung dengan kemampuan responden dalam mengetahui cara pembuatan pupuk organik cair yang baik dan benar. Hal ini ditandai dengan adanya kemampuan responden dalam menguraikan faktor-faktor yang dapat mempengaruhi dalam pembuatan POC, artinya berkaitan dengan kendala yang dihadapi dalam pembuatan pupuk organik cair. Kemudian responden dapat memahami dimana pupuk organik cair harus selalu diperhatikan dan diawasi sehingga faktor-faktor penghambat dalam pembuatan POC dapat diatasi, artinya $\mathrm{pH}$, kelembaban dan waktu dalam pembuatan POC harus diperhatikan. Didukung dengan kemampuan responden dalam mensintesa, artinya kemampuan responden yang menuntut untuk menghasilkan sesuatu yang baik dan menguntungkan.

Evaluasi tingkat pengetahuan dilakukan setelah pelaksanaan kegiatan penyuluhan yang menggunakan metode ceramah dan diskusi, media folder, video dan slide. Suzuki (1984) didalam Mardikanto (2008:) mengemukakan bahwa metode ceramah dan diskusi dapat menggunakan media cetak dan terproyeksi untuk pendekatan melalui kelompok. Menurut Mardikanto (2008) berdasarkan media, ranah perilaku yang dipengaruhi pengetahuan yaitu benda (contoh/sample, specimen, model), barang cetakan (poster, placard, selebaran), gambar yang di proyeksikan (video, TV, VCD, movie-film, filmstrip, slide). Sehingga, metode dan media yang digunakan untuk kegiatan penyuluhan berdampak pada tingginya tingkat pengetahuan peternak.

\section{Aspek Sikap}

Tabel 5. Rekapitulasi Tingkat Sikap Responden

\begin{tabular}{lccc}
\hline \multicolumn{1}{c}{ Kategori Skor } & Jumlah Orang & Rata-rata Skor & Persentase (\%) \\
\hline Tidak menerima (20-40) & - & - & - \\
Cukup menerima (41-60) & - & - & - \\
Menerima (61-80) & 10 & 77 & 50 \\
Sangat Menerima (81-100) & 10 & 85 & 50 \\
\hline Jumlah & $\mathbf{2 0}$ & & $\mathbf{1 0 0}$ \\
\hline
\end{tabular}

Sumber: Data Evaluasi, 2018.

Berdasarkan hasil rekapitulasi data sikap responden pada Tabel5, diperoleh ratarata yaitu 85 untuk kategori sangat menerima dan rata-rata skor sebesar 77 untuk kategori menerima. Responden dengan kategori skor menerima dan sangat menerima jumlahnya sama yaitu masing-masing sepuluh orang. Berdasarkan hasil tersebut responden memiliki 
Triyogi Gitadevarsa, Setya Handayani dan Andi Warnaen, Rancangan Penyuluhan Tentang Proses Pembuatan Pupuk Organik Cair dari Urine Sapi Potong Menggunakan Mikroorganisme Lokal (MOL) Bongkol Pisang Di Desa Wonorejo Kecamatan Lawang Kabupaten Malang

sikap menerima inovasi tentang pembuatan POC dari urine sapi potong menggunakan MOL bonggol pisang.

Tabel 6. Persentase Aspek Afektif Menurut Taksonomi Bloom

\begin{tabular}{lc}
\hline \multicolumn{1}{c}{ Dimensi Sikap (A) } & Persentase (\%) \\
\hline Menerima (A1) & 40,15 \\
Respon (A2) & 30,82 \\
Menilai (A3) & 19,21 \\
Mengelola (A4) & 9,82 \\
\hline
\end{tabular}

Sumber: Data Hasil Evaluasi, 2018.

Sikap responden tentang pembuatan POC dari urine sapi menggunakan MOL bonggol pisang berada pada tahap menerima dan merespon. Sikap menerima ini didukung dengan tingginya sikap responden dalam menerima inovasi yang diberikan, artinya bahwa sikap responden terhadap inovasi yang diberikan dalam penyuluhan tidak bertolak belakang dengan sosial budaya yang ada serta mudah dalam mendapatkan segala keperluan yang dibutuhkan dalam pembuatan POC. Kemudian responden juga merespon atau menanggapi tentang inovasi yang diberikan, artinya bahwa sikap responden yang menunjukkan partisipatif aktif mengikutsertakan dirinya dalam kegiatan penyuluhan. Hal ini dapat dilihat dari daya tarik fisik, pesan dan inovasi teknologi yang disampaikan dalam penyuluhan tentang pembuatan pupuk organik cair.

Evaluasi sikap dilakukan setelah pelaksanaan kegiatan penyuluhan yang menggunakan metode ceramah dan diskusi, media folder, video dan slide. Menurut Mardikanto (2008) berdasarkan media, ranah perilaku yang dipengaruhi sikap yaitu benda (contoh/sampel, model), barang cetakan (brosur, folder, flipchart, leaflet, flanel-graph), gambar yang diproyeksikan (transparancy, slide, film-strip). Sehingga media yang digunakan dapat menarik respon yang baik dari petani peternak.

\section{Aspek Keterampilan}

Tabel 7. Rekapitulasi Tingkat Keterampilan Responden

\begin{tabular}{llll}
\hline Kategori Skor & Jumlah Orang & Rata-rata Skor & Persentase (\%) \\
\hline Tidak terampil (0-10) & - & - & - \\
Terampil (11-20) & 20 & 16,5 & 100 \\
\hline Jumlah & $\mathbf{2 0}$ & & $\mathbf{1 0 0}$
\end{tabular}

Sumber: Data Evaluasi, 2018.

Data keterampilan responden pada Tabel 7 , diperoleh rata-rata untuk kategori trampil sebesar 16,4. Berdasarkan hasil tersebut seluruh responden terampil dalam pembuatan POC dari urine sapi potong menggunakan MOL bonggol pisang.

Tabel. 8 Persentase Aspek Psikomotorik Menurut Taksonomi Bloom

\begin{tabular}{lc}
\hline \multicolumn{1}{c}{ Dimensi Keterampilan (P) } & Persentase (\%) \\
\hline Meniru (P1) & 44,38 \\
Memanipulasi (P2) & 15,50 \\
Pengalaman (P3) & 40,12 \\
\hline
\end{tabular}

Sumber: Data Hasil Evaluasi, 2018.

Tabel 8 menunjukkan bahwa terampilnya responden didukung dengan tingginya kemampuan meniru untuk melakukan sesuatu dengan contoh yang diamati walaupun belum dimengerti makna ataupun hakikat dari ketrampilan itu. Berawal dari penyuluhan 
Triyogi Gitadevarsa, Setya Handayani dan Andi Warnaen, Rancangan Penyuluhan Tentang Proses Pembuatan Pupuk Organik Cair dari Urine Sapi Potong Menggunakan Mikroorganisme Lokal (MOL) Bongkol Pisang Di Desa Wonorejo

Kecamatan Lawang Kabupaten Malang

tentang tahapan pembuatan pupuk organik cair dari urine sapi menggunakan MOL bonggol pisang yang dimana nantinya dapat ditiru oleh peternak untuk pengembangan usaha kedepannya.

Evaluasi tingkat keterampilan dilakukan bersamaan dengan kegiatan pembuatan pupuk organik cair yang menggunakan metode kaji terap dan demonstrasi hasil, media benda sesungguhnya. Metode penyuluhan kaji terap dan demonstrasi hasil dapat menggunakan media lisan, media-cetak, dan media terproyeksi, serta pendekatan psikososial secara kelompok (Mardikanto, 2008). Menurut Mardikanto (2008) berdasarkan media, ranah perilaku yang dipengaruhi ketrampilan yaitu benda (contoh/sampel, model), barang cetakan (brosur, flanel-graph, folder, leaflet), gambar yang diproyeksikan (video, TV, VCD, DVD, slide, film-strip). Sehingga media dan metode yang digunakan dapat meningkatkan ketrampilan peternak

\section{KESIMPULAN}

Hasil uji laboratorium kandungan POC diperoleh C-organik sebesar 0,82\%, $\mathrm{pH}$ 7,37, $\mathrm{N}$ sebesar 0,06\%, $\mathrm{P}_{2} \mathrm{O}_{5}$ sebesar 0,004\% ( $\left.\mathrm{P}=0.001744 \%\right)$ dan $\mathrm{K}_{2} \mathrm{O}$ sebesar 4,13\% $(\mathrm{K}=3.4279 \%)$. Rancangan Penyuluhan adalah meliputi Tujuan, Agar Petani Peternak tahu, mau, dan mampu membuat pupuk organik cair dari urine sapi potong menggunakan MOL bongkol pisang yang benar. Sasaran, KelompokTani Karya Makmur II sebanyak 20 orang. Materi, Pembuatan MOL bonggol pisang dan pembuatan Pupuk Organik Cair dari urine sapi. Metode, Ceramah, diskusi dan kaji terap. Media, Power point (slide), video, benda sesungguhnya dan folder. Perilaku peternak menunjukan bahwa Pada aspek pengetahuan berdasarkan teori bloom peternak sudah berada pada ranah pengetahuan dan memahami. Pada aspek sikap berdasarkan teori bloom peternak sudah berada pada ranah menerima dan menanggapi. Pada aspek keterampilan berdasarkan teori bloom peternak sudah berada pada ranah meniru.

\section{DAFTAR PUSTAKA}

Hadisuwito. 2002. Evaluasi Kesuburan Tanah. http://www.pustaka-deptan.go.id. Diakses tanggal 23 Januari 2018.

Hidayanti, Y., B, Kurnani., E, Marlina., Harlia. 2011. Kualitas Pupuk Organik Cair Hasil Pengelolahan Feses Sapi Potong Menggunakan Saccharomyces cereviceae (Liquid Fertilizer Quality Produced by Beef Cattle Feces Fermentation Using Saccharomyces cereviceae). Jurnal Ilmu Ternak Vol. 11, No. 2. 104107. Fakultas Peternakan Universitas Padjadjaran, Bandung.

Hidayati, YA. Bento TB., Kunarni A., Marlina E.T., dan Harlina E. 2008. Kualitas pupuk cair hasil pengolahan feses sapi potong menggunakan saccharomyces cerevisiae. Jurnal Ilmu Ternak. 11 (2): $104-107$.

Huda, Muhammad Khoirul. 2013. PembuatanPupuk Organik dari Urin Sapi dengan Aditif Tetes Tebu (Molase) Metode Fermentasi. Skripsi Program Studi Kimia. Universitas Negeri Semarang. 
Triyogi Gitadevarsa, Setya Handayani dan Andi Warnaen, Rancangan Penyuluhan Tentang Proses Pembuatan Pupuk Organik Cair dari Urine Sapi Potong Menggunakan Mikroorganisme Lokal (MOL) Bongkol Pisang Di Desa Wonorejo Kecamatan Lawang Kabupaten Malang

Kusuma, A. P., Istirokkhatun, T., dan Purwono. 2007. Pengaruh Penambahan Urin Sapi Dan Molase Terhadap Kandungan C Organik Dan Nitrogen Total Dalam Pengolahan Limbah Padat Isi Rumen Rph Dengan Pengomposan Aerobik. Jurnal Teknik Lingkungan, Vol. 6, No. 1 (2017) Departemen Teknik Lingkungan Fakultas Teknik Universitas Diponegoro. Semarang.

Mardikanto, T., 2009. Sistem Penyuluhan Pertanian. Lembaga Pengembangan Pendidikan UNS dan UNS Press: Surakarta.

Mardikanto, T., 2008. Sistem Penyuluhan Pertanian. Lembaga Pengembangan Pendidikan UNS dan UNS Press: Surakarta.

Rahman, N. A. dan Setyawati, H. 2010. Pengaruh Variasi Sumber Karbon dan Waktu Fermentasi pada Proses Pembuatan Pupuk Organik Cair dari Kulit Pisang. ISSN: 1412-3819. Jurnal Teknologi Media Perspektif Vol. 10.

Sugiyono. 2016. Metode Penelitian Kombinasi (Mixed Methods). Edisi Kedelapan. Bandung: Alfabeta.

Syam, M. 2017. Kandungan Nitrogen Pupuk Organik Cair (POC) Asal Urin Sapi dengan Penambahan PGPR (Plant Grow Promotting Rhizobacteria) Akar Serai Melalui Fermentasi. Fakultas Sains dan Tekhnologi. Universitas Islam Negeri Makassar.

Warnaen Andi, Cangara Hafied, Bulkis Siti. 2013. Faktor-Faktor yang Menghambat Inovasi pada Komunitas Petani dan Nelayan dalam Meningkatkan Kesejahteraan Masyarakat di Kabupaten Takalar. (Vol. 2 No. 3 Juli- September 2013). Makassar; Jurnal Komunikasi Kareba

Wulandari, R., M, Junus., E. Setyowati. 2015. Pengaruh Aerasi dan Penambahan Silika dengan Pemeraman yang Berbeda terhadap Kandungan N, P dan K Pupuk Cair Unit Gas Bio. Jurnal. Fakultas Peternakan, Universitas Brawijaya, Malang. 